\title{
Traffic-generated changes in the elemental profile of urban coarse dust at a highway and crossroads
}

\author{
Wioletta Rogula-Kozłowska ${ }^{1 *}$, Karolina Kuskowska ${ }^{2}$, Pawet Ogrodnik ${ }^{1}$ and Magdalena \\ Penkała $^{3}$ \\ ${ }^{1}$ The Main School of Fire Service, Faculty of Fire Safety Engineering, 52/54 Słowackiego St., 01-629 \\ Warsaw, Poland, \\ ${ }^{2}$ The Main School of Fire Service, Faculty of Civil Safety Engineering, Slowackiego 52/54, 01-629 \\ Warsaw, Poland \\ ${ }^{3}$ The State School of Higher Education, 54 Pocztowa St., 22-100 Chełm, Poland
}

\begin{abstract}
Based on literature data, the percentage contribution of road traffic to concentrations of particulate matter (PM) and PM-bound elements, separately for $\mathrm{PM}_{2.5-10}$ and $\mathrm{PM}_{10-100}$ fractions were assessed. The data on the $\mathrm{PM}_{2.5-10}$ and $\mathrm{PM}_{10-100}$ concentrations examined simultaneously at two locations (the $1^{\text {st }}$ outside the direct impact of the road emission; the $2^{\text {nd }}$ next to a crossroads or highway) were used in the analysis. There were clear differences in the concentrations of PM and its components between these locations (a crossroads vs. background; highway vs. background). Both PM concentrations and concentrations of the majority of the $\mathrm{PM}_{2.5-}$ 10- and $\mathrm{PM}_{10-100}$-bound elements had higher values in the traffic site. The percentage increase of PM concentrations was in the range from $25\left(\mathrm{PM}_{2.5-}\right.$ 10 ; highway) to $606 \%$ ( $\mathrm{PM}_{10-100}$; crossroads). The highest percentage increase in the concentration of elements was noted at the crossroads, where concentrations of $\mathrm{PM}_{10-100-b o u n d} \mathrm{Si}, \mathrm{Sc}, \mathrm{Fe}$ and $\mathrm{Pb}$ were 12, 22, 25 and 71 times higher than at the urban background site, respectively. The measurable results of this paper are elemental profiles of two coarse fractions of PM in the vicinity of the road and crossroads and at sites far apart from the big road traffic sources. The collected information can be an important source of knowledge in identifying the origin of PM in the receptor.
\end{abstract}

\section{Introduction}

It is not entirely clear whether and in what way the occurence of various elements in particulate matter (PM) affects its toxic properties. They are dependent not only on the quantity of a certain element or group of elements, but also among other things on: the size of particles with which elements are associated, the content of PM other toxic compounds, the reaction of atmospheric aerosol, as well as from other environmental factors to which the studied population is subjected.

\footnotetext{
* Corresponding author: wrogula@sgsp.edu.pl
} 
The, so called heavy metals associated with dust are unequivocally considered to be deletrimental to health [1-4]. This is one of the reasons why As, $\mathrm{Cd}, \mathrm{Co}, \mathrm{Cr}, \mathrm{Mn}, \mathrm{Ni}, \mathrm{Pb}$ and $\mathrm{V}, \mathrm{Fe}, \mathrm{Cu}, \mathrm{Zn}, \mathrm{Ba}$ are the most examined group of components of the PM. Concentrations not only of PM, but also elements associated with PM are very much dependent on location. The proximity of significant emissions sources can have a decisive effect on the concentration of the whole group of metals or a few, or even only one of them. Therefore, an analysis of the chemical composition provides interesting data, not only for the assessment of the impact of PM on human health and the environment, but also for the identification of PM sources. It also facilitates understanding of the temporal and spatial variability of the source-receptor relationship and the effectiveness of strategies of emission reduction. One of the significant sources of metals in the air are vehicles. Crude oil, even before the refining process, contains small amounts of trace elements, which is causing these elements to usually occur in the fine PM emitted from its combustion $\left(\mathrm{PM}_{2.5}\right)[5,6]$. Metal compounds are also observed in the coarse particles fraction $\left(\mathrm{PM}_{2.5-10}\right.$, and also in particles with an aerodynamic diameter exceeding $10 \mu \mathrm{m}$ ) originating from non-exhaust traffic emissions, arising from, among others: the corrosion of cars elements, the wear of brake discs and blocks, and the abrasion of clutch plates, tires and road surfaces [7-10]. The precious metal compounds produced during the exploitation of catalytic converters supply both fine and coarse PM [11].

Traffic emissions are one of the main sources of emissions of metals and other trace elements into the air in urban areas where high emission is not related to industry or energy. Due to the above, concentrations of PM-related elements are often monitored at locations exposed to the direct impact of non-exhaust traffic emissions [6-10, 12-18]. So far in Poland, research into PM and PM characteristics in the vicinity of roads and crossroads have been studied mainly in the area of Upper Silesia [19-28].

The aim of the study was the assessment of the impact of road traffic on the concentrations of selected elements associated with two fractions of coarse particles suspended at the highway in Katowice and at the crossroads in Zabrze. The analysis was based on selected available data from Upper Silesia (Poland) published in [24-27]. In addition, an analyses of the percentage of elements in PM mass and the contribution of road traffic emissions to PM and PM-bound elements concentrations were assessed.

\section{Experimental}

Data on the concentrations of coarse particles: $\mathrm{PM}_{2.5-10}, \mathrm{PM}_{10-100}$ and $\mathrm{PM}_{2.5-10^{-}}$and $\mathrm{PM}_{10-100^{-}}$ bound elements were taken from four publications in which the mass size distribution of PM and PM-bound species in different points of Upper Silesia were shown and described [24-27]. The data on the $\mathrm{PM}_{2.5-10}$ and particles with an aerodynamic diameter $>10 \mu \mathrm{m}$ was examined simultaneusly in the two pairs of locations that were used (Table 1).

One of the measurement sites was located outside the direct impact of road traffic emission (the so-called urban site); the other was located at a crossroads and at a highway (traffic site). The locations of both pairs are described in detail in the source papers [24-27]. The above-mentioned works also describe in detail the methodology for the measuring of PM concentrations in the atmospheric air, the parameters and equipment used in PM measurements and chemical analysis. The data used relates to two periods: spring-summer and summer-autumn; in other words, periods in which a significant local emission of PM and its compounds from individual house heating in the region, is relatively small $[4,21$, 22, 29].

Based on the average values of concentrations at four different measurement sites (two pairs of measurement locations: HWK - highway in Katowice vs. UBK - urban backgroud site in Katowice and CRZ - crossroads in Zabrze vs. UBZ - urban backgroud site in 
Zabrze), the so-called contribution (percentage) of non-exhaust traffic emission (or road traffic) to concentrations of dust and its components, separately for $\mathrm{PM}_{2.5-10}$ and $\mathrm{PM}_{10-100}$ was calculated.

Table 1. Data on means in the periods of measurement ambient concentrations of $\mathrm{PM}_{2.5-10}, \mathrm{PM}_{10-100}$ $\left(\mu \mathrm{g} / \mathrm{m}^{3}\right)$ and PM-bound elements $\left(\mathrm{ng} / \mathrm{m}^{3}\right)$ taken from [24-27].

\begin{tabular}{|c|c|c|c|c|c|c|c|c|}
\hline & \multicolumn{2}{|c|}{ *HWK } & \multicolumn{2}{|r|}{ UBK } & \multicolumn{2}{|r|}{ CRZ } & \multicolumn{2}{|r|}{ UBZ } \\
\hline & $\mathrm{PM}_{10-}$ & $\mathrm{PM}_{2.5-}$ & $\mathrm{PM}_{10}$ & $-100 \mathrm{PM}_{2.5}$ & ${ }_{0} \mathrm{PM}_{10-}$ & ${ }_{100} \mathrm{PM}_{2.5-}$ & ${ }_{0} \mathrm{PM}_{1 \mathrm{C}}$ & ${ }_{100} \mathrm{PM}_{2.5-10}$ \\
\hline$\overline{\mathrm{PM}}$ & 1.2 & 4.7 & 0.8 & 3.8 & 1.3 & 7.3 & 0.2 & 3.1 \\
\hline $\mathrm{Al}$ & 11.0 & 43.7 & 8.2 & 40.6 & 38.5 & 159.6 & 7.4 & 69.3 \\
\hline $\mathrm{Si}$ & 46.4 & 167.0 & 31.9 & 146.7 & 118.4 & 411.4 & 9.1 & 150.1 \\
\hline $\mathrm{Sc}$ & 4.8 & 15.7 & 2.3 & 14.2 & 18.4 & 61.1 & 0.8 & 25.4 \\
\hline $\mathrm{Ti}$ & 15.0 & 48.7 & 14.3 & 48.8 & 6.5 & 23.3 & 3.7 & 13.2 \\
\hline V & 2.0 & 6.9 & 1.9 & 6.7 & 1.0 & 11.1 & 0.6 & 2.0 \\
\hline $\mathrm{Cr}$ & 0.7 & 2.4 & 0.7 & 2.2 & 0.4 & 1.1 & 0.3 & 1.5 \\
\hline $\mathrm{Mn}$ & 5.2 & 19.0 & 4.4 & 18.2 & 3.1 & 12.0 & 0.9 & 4.6 \\
\hline $\mathrm{Fe}$ & 42.7 & 264.5 & 27.1 & 175.3 & 111.8 & 486.8 & 4.2 & 129.6 \\
\hline $\mathrm{Co}$ & 0.4 & 1.3 & 0.3 & 1.1 & 0.7 & 25.3 & 0.3 & 6.9 \\
\hline $\mathrm{Ni}$ & 0.1 & 0.4 & 0.1 & 0.3 & 0.5 & 4.1 & 0.1 & 2.1 \\
\hline $\mathrm{Cu}$ & 0.8 & 6.7 & 0.6 & 4.4 & 1.5 & 6.9 & 0.2 & 1.7 \\
\hline $\mathrm{Zn}$ & 3.8 & 14.5 & 1.6 & 11.6 & 4.2 & 19.5 & 6.7 & 7.6 \\
\hline As & 0.4 & 1.6 & 0.4 & 1.9 & 0.7 & 1.3 & 1.1 & 3.0 \\
\hline $\mathrm{Se}$ & 0.0 & 0.0 & 0.0 & 0.0 & 0.3 & 0.2 & 0.3 & 0.6 \\
\hline $\mathrm{Br}$ & 0.2 & 0.5 & 0.1 & 0.6 & 0.8 & 1.0 & 1.2 & 1.7 \\
\hline $\mathrm{Rb}$ & 0.0 & 0.1 & 0.0 & 0.1 & 0.6 & 1.5 & 0.1 & 0.8 \\
\hline $\mathrm{Sr}$ & 0.4 & 1.5 & 0.3 & 1.4 & 0.5 & 2.2 & 0.4 & 1.9 \\
\hline Mo & 0.2 & 0.8 & 0.1 & 0.5 & 0.1 & 0.3 & 0.2 & 0.4 \\
\hline $\mathrm{Ag}$ & 0.3 & 0.8 & 0.2 & 0.9 & 0.5 & 3.1 & 0.3 & 0.9 \\
\hline $\mathrm{Cd}$ & 0.4 & 1.2 & 0.4 & 1.2 & 0.9 & 2.1 & 0.3 & 2.1 \\
\hline $\mathrm{Sb}$ & 7.0 & 22.3 & 6.7 & 22.8 & 1.7 & 5.3 & 1.7 & 4.2 \\
\hline $\mathrm{Te}$ & 0.1 & 0.5 & 0.3 & 0.8 & 0.1 & 0.5 & 0.1 & 1.4 \\
\hline $\mathrm{Ba}$ & 2.1 & 9.8 & 1.9 & 7.6 & 2.6 & 9.0 & 0.7 & 7.2 \\
\hline $\mathrm{Pb}$ & 1.2 & 4.6 & 1.1 & 5.5 & 2.2 & 4.3 & 0.0 & 3.0 \\
\hline
\end{tabular}

*HWK - highway in Katowice; UBK - urban backgroud site in Katowice; CRZ - crossroads in Zabrze; UBZ urban backgroud site in Zabrze)

Contribution (percentage) of non-exhaust traffic emission $\Delta \mathrm{C}_{p f i}$ to concentration of $i$-th pollution associated with the dust fraction $f$ at the measurement site $p$ is the ratio of the difference between the concentration of this contaminant at this site $\left(\mathrm{C}_{p f i}\right)$ and in the background $\left(\mathrm{T}_{f i}\right)$ to the background concentration:

$$
\Delta C_{p f i}=\frac{C_{p f i}-T_{f i}}{T_{f i}} * 100 \%
$$

This value illustrates that the percentage in relation to the "background concentration" can increase values of concentration in sites where non-exhaust traffic emission has a visible effect.

\section{Results and discussion}

The compiliation of contributions of non-exhaust traffic emission (\%) to concentrations of dust and its components, separately for $\mathrm{PM}_{2.5-10}$ and $\mathrm{PM}_{10-100}$ was calculated on the basis of data collected in Table 1 is presented in Table 2. 
Table 2. Contribution of non-exhaust traffic emission $\left(\Delta \mathrm{C}_{p f i}, \%\right)$ at the highway in Katowice (HWK) and at the crossroads in Zabrze (CRZ) $(p)$ to the concentrations of $\mathrm{PM}_{2.5-10}$ i $\mathrm{PM}_{10-100}(f)$ and its components.

\begin{tabular}{|c|c|c|c|c|}
\hline (i) & $\triangle \mathrm{C}_{H W K P M I 0-100}$ & $\Delta \mathrm{C}_{H W K P M 2.5-10}$ & $\triangle \mathrm{C}_{C R Z P M 10-100}$ & $\begin{array}{l}\Delta \mathrm{C}_{C R Z P M 2.5-} \\
10\end{array}$ \\
\hline PM & 58 & 25 & 606 & 139 \\
\hline $\mathrm{Al}$ & 34 & 8 & 419 & 130 \\
\hline $\mathrm{Si}$ & 46 & 14 & 1207 & 174 \\
\hline $\mathrm{Sc}$ & 111 & 11 & 2168 & 140 \\
\hline $\mathrm{Ti}$ & 5 & 0 & 75 & 76 \\
\hline V & 4 & 4 & 72 & 462 \\
\hline $\mathrm{Cr}$ & 9 & 7 & 50 & -24 \\
\hline $\mathrm{Mn}$ & 19 & 4 & 238 & 162 \\
\hline $\mathrm{Fe}$ & 57 & 51 & 2576 & 276 \\
\hline Co & 28 & 16 & 143 & 264 \\
\hline $\mathrm{Ni}$ & 10 & 32 & 350 & 100 \\
\hline $\mathrm{Cu}$ & 44 & 53 & 753 & 311 \\
\hline $\mathrm{Zn}$ & 144 & 25 & -37 & 158 \\
\hline As & 2 & -14 & -32 & -56 \\
\hline $\mathrm{Se}$ & - & -57 & -13 & -67 \\
\hline $\mathrm{Br}$ & 32 & -16 & -31 & -43 \\
\hline $\mathrm{Rb}$ & -18 & -7 & 556 & 90 \\
\hline $\mathrm{Sr}$ & 49 & 10 & 44 & 12 \\
\hline Mo & 124 & 69 & -43 & -23 \\
\hline $\mathrm{Ag}$ & 14 & -13 & 68 & 234 \\
\hline $\mathrm{Cd}$ & -9 & -2 & 167 & -3 \\
\hline $\mathrm{Sb}$ & 4 & -2 & 4 & 27 \\
\hline $\mathrm{Te}$ & -49 & -32 & 43 & -67 \\
\hline $\mathrm{Ba}$ & 11 & 29 & 289 & 25 \\
\hline $\mathrm{Pb}$ & 6 & -16 & 7100 & 46 \\
\hline
\end{tabular}

Comparing the values of contributions of non-exhaust traffic emission calculated for the pairs: HWK vs UBK and CRZ vs. UBZ can be seen that clearly larger are contributions to $\mathrm{PM}$ concentration and a concentration of the majority of $\mathrm{PM}_{2.5-10}$ and $\mathrm{PM}_{10-100}$-bound elements for the traffic site in Zabrze, in other words for a large crossroads. At this location, the percentage increase of $\mathrm{PM}_{10-100}$ was $600 \%$, and $\mathrm{PM}_{2.5-10}$ was $139 \%$. It means that the concentrations of these particles suspended in the air at the crossroads were 6 and 1.5 times higher, respectively, than at the urban background site. For the HWK-UBK pair, the values of the contribution of emission from road traffic to PM concentration were definitely lower than for the CRZ-UBZ pair and were respectively equal $58 \%$ for $\mathrm{PM}_{10-100}$ and $25 \%$ for $\mathrm{PM}_{2.5-10}$. The difference between the impact of road traffic at both locations is directly related to the fact that at the CRZ location PM and PM-bound elements concentrations were definitely higher than at the HWK location. CRZ is a large and heavy traffic crossroads of five large streets, which are congested for most of the day; in addition, there is a tram line running alongside it. One of the crossing roads is the access road to a large shopping center. All this results in the fact that the PM generated by road traffic in this site is practically "trapped" in the vicinity of the crossroads and its relocation over greater distances is difficult. It should also be pointed out that in studies of the contributions of roads traffic to concentrations of $\mathrm{PM}_{2.5}$ and $\mathrm{PM}_{10}$ carried out in 2004-2006 at this crossroads, very high periodic concentrations of coarse $\mathrm{PM}_{2.5-10}$ dust were noted [20,21]. On the other hand, in studies carried out in 2006 at the highway in Katowice, very similar mean values of $\Delta \mathrm{C}_{p f i}$ (48.8\% for $\mathrm{PM}_{2.5}$ and $52.9 \%$ for $\mathrm{PM}_{10}$ ) were obtained in a completely different averaging period (apart from the summer period, examined were conducted also in April, May and December) [24]. According to Table 2, in both measurement locations, i.e. both at the 
crossroads in Zabrze and at the roadside of highway in Katowice, the values of contributions of road traffic to the concentration of PM-bound elements were determined by various, both positive and negative, values. The share of contributions larger than $100 \%$, i.e. those which indicate the increase in concentrations of elements due to the impact of road traffic emission, were respectively: $6.5 \% \Delta \mathrm{C}_{H W K P M 10-100,} 0 \% \Delta \mathrm{C}_{H W K P M 2.5-10}$, $46 \% \Delta \mathrm{C}_{C R Z P M 10-100}, 50 \% \Delta \mathrm{C}_{C R Z P M 2.5-10}$. Therefore, it is not possible to unambiguously determine one approximate value of $\Delta \mathrm{C}_{p f i}$ for one element, group of elements or even PM fraction. Nevertheless, the data presented in Table 2 show that for both analyzed pairs (HWK vs. UBK and CRZ vs. UBZ) higher values of contributions of non-exhaust traffic emission to concentrations of $\mathrm{PM}_{10-100}$ and to concentrations of most of $\mathrm{PM}_{10-100}$-bound elements are higher than to concentrations of $\mathrm{PM}_{2.5-10}$ and concentrations of elements associated with this fraction. The highest percentage increases in PM-bound elements concentrations were calculated for: lead, iron, scandium, silicon and copper related to the $\mathrm{PM}_{10-100}$ fraction at the traffic site in Zabrze. The concentrations of these elements were 71, 25, 22, 12 and 7 times higher, respectively, at the traffic site than the concentrations of these elements associated with $\mathrm{PM}_{10-100}$ in the urban location. The highest percentage increas in $\mathrm{PM}_{2.5-10}$ concentrations caused by emission from road traffic were reported for vanadium, copper, iron, cobalt and reached $462 \%, 311 \%, 276 \%$ and $264 \%$ respectively. The contributions to concentrations of elements associated with $\mathrm{PM}_{10-100}$ for a pair of HWK vs. UBK were the highest for zinc, molybdenum, scandium and iron and reached values in the range of $57-144 \%$ and for $\mathrm{PM}_{2.5-10}$-bound elements the highest values within the limits of $25-69 \%$ were recorded for molybdenum, copper, iron, barium and zinc. Among the listed elements, iron, copper and scandium are elements which repeated in both analyzed pairs of locations and for both PM fractions. The occurrence of these elements in the atmospheric air can be associated with the impact of traffic emissions, specifically with the abrasion of tires and road surfaces (asphalt, paint, etc.) resulting from traffic [8-11,18], the combustion of fuels and their compounds $[5,6,10]$ or the abrasion of brake blocks and pads $[8-11,18]$.

In Table 3, the elements associated with the $\mathrm{PM}_{2.5-10}$ and $\mathrm{PM}_{10-100}$ were collated into five intervals. Each of them represents the range of values of the percentage contributions of individual elements in PM mass. Analyzing the percentage share of particular elements in PM mass at HWK and CRZ traffic sites, a significant share in the mass of coarse PM, mainly so-called crustal elements, i.e. aluminum, silicon and titanium, but also other components, among others scandium, titanium, iron and lead may be noticed. The crustal ingredients not only mainly come from a mixture of road and soil dust which is raised from the surface and carried in the vicinity of roads and crossroads during the movement of vehicles and pedestrians, but they are also due to the impact of wind. Due to the fact that both soil in cities and dust from non-exhaust sources are contaminated with various elements, their increased amount at roads and crossroads affects the occurrence of the entire spectrum of elements in the coarse PM. Therefore, the elemental profiles of the coarse dust at traffic sites and urban background sites are significantly different (Table 3). 
Table 3. Percentage mass contributions of the elements in two fractions of coarse PM in selected traffic and urban sites.

\begin{tabular}{|c|c|c|c|c|c|}
\hline Traffic & $<0.01 \%$ & $0.01-0.1 \%$ & $0.1-1 \%$ & $1-5 \%$ & $>5 \%$ \\
\hline \multicolumn{6}{|c|}{ HWK } \\
\hline $\mathrm{PM}_{10-100}$ & $\begin{array}{l}\text { *Se, } \mathrm{Rb} \\
\mathrm{Ni}\end{array}$ & $\begin{array}{c}\mathrm{Te}, \mathrm{Br}, \mathrm{Mo}, \mathrm{Ag}, \mathrm{Co}, \mathrm{Cd}, \mathrm{As} \\
\mathrm{Sr}, \mathrm{Cr}, \mathrm{Cu}, \mathrm{Pb}\end{array}$ & $\mathrm{V}, \mathrm{Ba}, \mathrm{Zn}, \mathrm{Sc}, \mathrm{Mn}, \mathrm{Sb}, \mathrm{Al}$ & $\begin{array}{l}\mathrm{Ti}, \mathrm{Fe} \\
\mathrm{Si}\end{array}$ & - \\
\hline $\mathrm{PM}_{2.5-10}$ & $\mathrm{Se}, \mathrm{Rb}$ & $\begin{array}{c}\mathrm{Ni}, \mathrm{Br}, \mathrm{Te}, \mathrm{Ag}, \mathrm{Mo}, \mathrm{Cd}, \mathrm{Co}, \\
\mathrm{Sr}, \mathrm{As}, \mathrm{Cr}\end{array}$ & $\begin{array}{c}\mathrm{Pb}, \mathrm{Cu}, \mathrm{V}, \mathrm{Ba}, \mathrm{Zn}, \mathrm{Sc}, \mathrm{Mn}, \\
\mathrm{Sb}, \mathrm{Al}\end{array}$ & $\mathrm{Ti}, \mathrm{Si}$ & $\mathrm{Fe}$ \\
\hline \multicolumn{6}{|c|}{ CRZ } \\
\hline $\mathrm{PM}_{10-100}$ & - & $\begin{array}{l}\text { Te, Mo, Se, Cr, Ni, Ag, Sr, } \\
\quad \text { Rb, Co, As, Br, Cd, V }\end{array}$ & $\mathrm{Cu}, \mathrm{Sb}, \mathrm{Pb}, \mathrm{Ba}, \mathrm{Mn}, \mathrm{Zn}, \mathrm{Ti}$ & $\mathrm{Sc}$ & $\begin{array}{l}\mathrm{Al}, \mathrm{Fe}, \\
\mathrm{Si}\end{array}$ \\
\hline $\mathrm{PM}_{2.5-10}$ & $\begin{array}{l}\text { Se, Mo, } \\
\text { Te }\end{array}$ & $\begin{array}{c}\mathrm{Br}, \mathrm{Cr}, \mathrm{As}, \mathrm{Rb}, \mathrm{Cd}, \mathrm{Sr}, \mathrm{Ag}, \mathrm{Ni} \\
\mathrm{Pb}, \mathrm{Sb}, \mathrm{Cu}\end{array}$ & $\mathrm{Ba}, \mathrm{V}, \mathrm{Mn}, \mathrm{Zn}, \mathrm{Ti}, \mathrm{Co}, \mathrm{Sc}$ & - & $\begin{array}{l}\mathrm{Al}, \mathrm{Si}, \\
\mathrm{Fe}\end{array}$ \\
\hline Urban & $<0.01 \%$ & $0.01-0.1 \%$ & $0.1-1 \%$ & $1-5 \%$ & $>5 \%$ \\
\hline \multicolumn{6}{|c|}{ UBK } \\
\hline $\mathrm{PM}_{10-100}$ & $\begin{array}{l}\mathrm{Se}, \mathrm{Rb} \\
\mathrm{Ni}\end{array}$ & $\begin{array}{c}\mathrm{Mo}, \mathrm{Br}, \mathrm{Ag}, \mathrm{Co}, \mathrm{Sr}, \mathrm{Te}, \mathrm{Cd} \\
\mathrm{As}, \mathrm{Cu}, \mathrm{Cr}\end{array}$ & $\mathrm{Pb}, \mathrm{Zn}, \mathrm{V}, \mathrm{Ba}, \mathrm{Sc}, \mathrm{Mn}, \mathrm{Sb}$ & $\begin{array}{l}\mathrm{Al}, \mathrm{Ti} \\
\mathrm{Fe}, \mathrm{Si}\end{array}$ & - \\
\hline $\mathrm{PM}_{2.5-10}$ & $\begin{array}{l}\mathrm{Se}, \mathrm{Rb} \\
\mathrm{Ni}\end{array}$ & $\begin{array}{c}\mathrm{Mo}, \mathrm{Br}, \mathrm{Te}, \mathrm{Ag}, \mathrm{Co}, \mathrm{Cd}, \mathrm{Sr}, \\
\mathrm{As}, \mathrm{Cr}\end{array}$ & $\mathrm{Cu}, \mathrm{Pb}, \mathrm{V}, \mathrm{Ba}, \mathrm{Zn}, \mathrm{Sc}, \mathrm{Mn}, \mathrm{Sb}$ & $\begin{array}{l}\mathrm{Al}, \mathrm{Ti} \\
\mathrm{Si}, \mathrm{Fe}\end{array}$ & - \\
\hline \multicolumn{6}{|c|}{ UBZ } \\
\hline $\mathrm{PM}_{10-100}$ & - & $\mathrm{Pb}, \mathrm{Te}, \mathrm{Rb}, \mathrm{Ni}, \mathrm{Cu}$ & $\begin{array}{l}\mathrm{Mo}, \mathrm{Cr}, \mathrm{Co}, \mathrm{Ag}, \mathrm{Se}, \mathrm{Cd}, \mathrm{Sr}, \mathrm{V} \\
\quad \mathrm{Ba}, \mathrm{Sc}, \mathrm{Mn}, \mathrm{As}, \mathrm{Br}, \mathrm{Sb}\end{array}$ & $\begin{array}{l}\mathrm{Ti}, \mathrm{Fe} \\
\mathrm{Zn}, \mathrm{Al}\end{array}$ & $\mathrm{Si}$ \\
\hline $\mathrm{PM}_{2.5-10}$ & - & $\begin{array}{c}\mathrm{Mo}, \mathrm{Se}, \mathrm{Rb}, \mathrm{Ag}, \mathrm{Te}, \mathrm{Cr}, \mathrm{Cu} \\
\mathrm{Br}, \mathrm{Sr}, \mathrm{V}, \mathrm{Ni}, \mathrm{Cd}, \mathrm{Pb}, \mathrm{As}\end{array}$ & $\mathrm{Sb}, \mathrm{Mn}, \mathrm{Co}, \mathrm{Ba}, \mathrm{Zn}, \mathrm{Ti}, \mathrm{Sc}$ & $\begin{array}{l}\mathrm{Al}, \mathrm{Fe} \\
\mathrm{Si}\end{array}$ & - \\
\hline
\end{tabular}

*in each column elements were listed in ascending order

\section{Conclusions}

The affected road traffic emission sites, for which data on PM concentrations and chemical composition of coarse PM were used in this paper, are located in the centers of large cities. One location represents one of the main streets in Poland (highway) with very high traffic, and the other is a typical street canyon [24-27]. The results of analyses showed a direct and strong impact of road traffic emission on the concentrations and chemical composition of the coarse PM in both of these locations. However, it has been proven that road traffic shapes the concentrations and chemical composition of the very coarse dust as $\mathrm{PM}_{10-100}$ is much stronger than the concentrations and chemical composition of coarse dust belonging to the $\mathrm{PM}_{2.5-10}$ fraction. It was also shown that the impact of road traffic on the concentration and chemical composition of both coarse PM fractions is generally stronger in the case of a street canyon (a large crossroads in the city) than at a highway. The obtained percentage increases of coarse PM concentration and PM-bound elements 
concentrations can be considered as kinda of indicators of the quantitative impact of nonexhaust traffic emission on the chemical parameters of an urban aerosol in a region with a high emission level, of which Upper Silesia is a good example [4, 21, 22, 25, 26, 29]. A measurable effect of this paper is the element profiles of coarse PM that can represent street/road dust in the city. These profiles have been established for both the locations in the vicinity of the road and crossroads as well as at locations distant from road traffic sources (urban background). Such data is an important source of information in modeling PM source apportionment in various urban areas.

The article was realized within the statutory research co-financed by funds of the Ministry of Science and Higher Education transferred to the Faculty of Fire Safety Engineering of The Main School of Fire Service in 2018.

\section{References}

1. D.L. Costa, K.L. Dreher, Environ. Health Perspect. 105, 1053-1060 (1997)

2. D.J. Swaine, Fuel Process Technol. 65-66, 21-33 (2000)

3. K. Na, D.R. Cocker III, Southern California. Atmos. Res. 93, 793-800 (2009)

4. W. Rogula-Kozłowska, B. Błaszczak, S. Szopa, K. Klejnowski, I. Sówka, A. Zwoździak, M. Jabłońska, B. Mathews, Environ. Monitor and Assess. 185, 581-601 (2013)

5. J. C. Chow, J. Air Waste Manag. Assoc. 45, 320-382 (1995)

6. P. Sanderson, J.M. Delgado Saborit, R.M. Harrison, Atmos. Environ. 94, 353-365 (2014)

7. R.M. Harrison, A. Jones, J. Gietl, J. Yin, D. Green, Environ. Sci. Technol. 46, 65236529 (2012)

8. A. Thorpe, R.M Harrison, Sci. Total Environ. 400, 270-282 (2008)

9. P. Pant, R.M Harrison, Atmos. Environ. 77, 78-97 (2013)

10. M. Penkała, P. Ogrodnik, W. Rogula-Kozłowska, Environments, 5, 9 (2018)

11. L. I. Dias da Silva, J. E. de Souza Sarkis, F. M. Zanon Zotin, M. Castro Carneiro, A. A. Neto, A. dos Santos, A.G. da Silva, M.J. Baldini Cardoso, M. I. Couto Monteiro, Chemosphere. 71, 677-684 (2008)

12. M. Malandrino, M. Di Martino, G. Ghiotti, F. Geobaldo, M.M. Grosa, A. Giacomino, O. Abollino, Microchimical Journal 107, 76-85 (2013)

13. T. Moreno, A. Karanasiou, F. Amato, F. Lucarelli, S. Nava, G. Calzolai, M. Chiari, E. Coz, B. Artíñano, J. Lumbreras, R. Borge, E. Boldo, C. Linares, A. Alastuey, X. Querol, W. Gibbons, Atmos. Environ. 68, 33-44 (2013)

14. J. Aldabe, D. Elustondo, C. Santamaría, E. Lasheras, M. Pandolfi, A. Alastuey, X. Querol, J.M. Santamaría, Atmos. Res. 102, 191-205, (2011)

15. M.F.D. Gianini, R. Gehrig, A. Fischer, A. Ulrich, A. Wichser, C. Hueglin, Atmos. Environ. 54, 97-106, (2012)

16. A. Sánchez-Jiménez, M.R. Heal, I.J. Beverland, Atmos. Environ. 54, 667-678, (2012)

17. T. Szigeti, V.G. Mihucz, M. Óvári, A. Baysal, S. Atilgan, S. Akman, G. Záray, Microchemical Journal 107, 86-94, (2013)

18. F. Amato, S. Nava, F. Lucarelli, X. Querol, A. Alastuey, J.M. Baldasano, M. Pandolfi, Sci. Total Environ. 408, 4309-4318, (2010) 
19. B. Grynkiewicz-Bylina, B. Rakwic, J.S. Pastuszka, Pol. J. Environ. Stud. 14, 117-123 (2005)

20. J.S. Pastuszka, W. Rogula-Kozłowska, E. Zajusz-Zubek, Environ. Monit. Assess. 168, 613-627 (2010)

21. W. Rogula-Kozłowska, J.S. Pastuszka, E. Talik, Pol. J. Environ. Stud. 17, 539-548, (2008)

22. B. Kozielska, W. Rogula-Kozłowska, J.S. Pastuszka, Int. J. Environ. and Pollution, 53, 245-264 (2013)

23. W. Rogula-Kozłowska, P. Rogula-Kopiec, K. Klejnowski, J. Blaszczyk, Rocz. Ochr. Sr. 15, 1623-1644, (2013)

24. W. Rogula-Kozłowska, Bull. Environ. Contam. Toxicol. 93, 493-502, (2014)

25. W. Rogula-Kozłowska, Environ. Prot. Eng. 41, 15-29 (2015)

26. P. Rogula-Kopiec, B. Kozielska, W. Rogula-Kozłowska, Int. J. Environ. Res. 10, 531542, (2016)

27. W. Rogula-Kozłowska, Air protection in theory and practice 2014 (Konieczyński J. Ed.) 1, 133-149, IEES, Zabrze (2014)

28. Hinds W.C., Aerosol technology. Properties, behavior, and measurement of airborne particles, 2nd edn. Wiley, New York, (1998)

29. W. Rogula-Kozłowska, K. Klejnowski, P. Rogula-Kopiec, L. Ośródka, E. Krajny, B. Błaszczak, B. Mathews, Air Qual, Atmos. Health 7, 41-58 (2016) 